\title{
Monitoring brain multiparameters and hypothermia in severe traumatic brain injury
}

This article was published in the following Dove Press journal:

Neuropsychiatric Disease and Treatment

8 March 2017

Number of times this article has been viewed

Fernando Roberto de

Almir Ferreira de Andrade

Manoel Jacobsen Teixeira Wellingson Silva Paiva

Division of Neurological Surgery, Department of Neurology, University of São Paulo Medical School, São Paulo, Brazil
Correspondence: Wellingson Silva Paiva Division of Neurological Surgery, Department of Neurology, University of São Paulo Medical School, 255 Eneas Aguiar, 05403000 São Paulo, Brazil Tel +55 || $266 \mid 7226$

Fax +55 । I 25486906

Email wellingsonpaiva@yahoo.com.br

\section{Dear editor}

We read with great interest the recent study by Sun et al ${ }^{1}$ published in Neuropsychiatric Disease and Treatment. Intracranial hypertension (ICH) remains the most common cause of death in patients with traumatic brain injury (TBI). ${ }^{1}$ After the trauma, secondary injuries arise due to perfusion and molecular changes that begin after the moment of the trauma resulting from the interaction of intracerebral and extracerebral factors, which add to the neuronal injury. Hypotension, hypoglycemia, hypercapnia, respiratory hypoxia, anemic hypoxia, and electrolyte disturbances are the main factors associated with secondary injury, which can lead to ICH and cerebral hypoxia, thereby worsening the morbidity and death rates associated with brain injury. ${ }^{1,2}$ In this paper, the authors have discussed the multimodality intracranial monitoring carried out in 62 severe TBI patients, with evidence of hypothermia as a therapeutic strategy to adequately control intracranial pressure (ICP).

The study had well-established, rigid inclusion criteria to find adequate results, with early evaluation of patients subjected to screening for severe TBI and proper exclusion of systemic trauma.

It has already been established that adequate ICP management is important for the better outcome of severe TBI patients. ${ }^{1}$ However, it is important to emphasize that patients with severe TBI need complex management. Appropriate investigation is always recommended; however, treating ICH alone may not be sufficient for neuronal preservation, as factors related to oxygen concentration in brain tissues have to be taken into account and also there is a possibility that a few treatments carried out to reduce ICP may cause side effects..$^{3-6}$ In this context, we agree that multimodality monitoring aims to safely demonstrate the type of individual therapy that benefits the brain environment at each phase of treatment in the intensive care unit. The most important aim is to adequately demonstrate the procedures that had a poor benefit-risk profile or that could even harm the brain. ${ }^{7,8}$

The paper has also provided us a didactic solid concept of the major benefits of mild hypothermia for patients with the neuroprotective concept in intensive care unit. The authors discussed hypothermia value for the microscopic neurotransmitter environment, vascular and neuronal metabolic aspect. ${ }^{3,4,7}$

A total of five parameters (ICP, brain tissue partial pressure of oxygen [PbtO2], jugular venous oxygen saturation [SjvO2], cerebral perfusion pressure[CPP], and end-tidal carbon dioxide pressure [ETCO2]) were used in multimodality monitoring for a period of time that ranged from 1 to 7 days. The study has already demonstrated the benefits of all these five parameters by emphasizing the improvement due to 
hypothermia in neurointensive care unit, with a decrease in the absolute values of ICP. ${ }^{3-5,9,10}$

However, some points need to be clarified by the authors. A wide age criterion ranging from 18 to 72 years can be a problem for analyzing the results. The authors also have not reported on which decompressive craniectomy-indicating protocol was used and what ICP limit was adopted.

Another point to be noted is the controversial discussion of the real role of hypothermia in TBI. Experimental studies on hypothermia have shown good results with a reduction in morbidity and mortality rates. ${ }^{11,12}$ However, although there is evidence regarding ICP control and improved perfusion pressure, improvements were not confirmed clinically in the late functional recovery of patients. ${ }^{13}$ In this paper, the authors did not present patient outcomes, not even shortterm outcomes, which is perhaps the greatest limitation of the study. In clinical research, although the relevance of monitoring data is important, clinical status of patients is always the most important.

So, we tend to agree with the main conclusion of the study that multimodality intracranial monitoring has its value in the acute setting of severe TBI in the intensive care unit, but more studies are necessary to prove the probable benefits of this improvement for TBI patient care, with long-term outcomes assessment and trauma scales.

\section{Disclosure}

The authors report no conflicts of interest in this communication.

\section{References}

1. Sun HT, Zheng M, Wang Y, Diao Y, Zhao W, Wei Z. Monitoring intracranial pressure utilizing a novel pattern of brain multiparameters in the treatment of severe traumatic brain injury. Neuropsychiatr Dis Treat. 2016;12:1517-1523.

2. Andrade AF, Paiva WS, Amorim RL, Figueiredo EG, Rusafa Neto E, Teixeira MJ. The pathophysiological mechanisms following traumatic brain injury. Rev Assoc Med Bras. 2009;55(1):75-81.

3. Busto R, Globus M, Dietrich WD, Martinez E, Valdes I, Ginsberg MD. Effect of mild hypothermia on ischemia-induced release of neurotransmitters and free fatty acids in rat brain. Stroke. 1989;20(7):904-910.

4. Harris OA, Colford JM Jr, Good MC, Matz PG. The role of hypothermia in the management of severe brain injury: a meta-analysis. Arch Neurol. 2002;59(7):1077-1083.

5. Finkelstein RA, Alam HB. Induced hypothermia for trauma: current research and practice. J Intensive Care Med. 2010;25(4):205-226.

6. Unterberg AW, Kiening KL, Hartl R, Bardt T, Sarrafzadeh AS, Lanksch WR. Multimodal monitoring in patients with head injury: evaluation of the effects of treatment on cerebral oxygenation. J Trauma. 1997; 42(5 Suppl):S32-S37.

7. De Georgia MA, Deogaonkar A. Multimodal monitoring in the neurological intensive care unit. Neurologist. 2005;11(1):45-54.

8. Bardt TF, Unterberg AW, Kiening KL, Schneider GH, Lanksch WR. Multimodal cerebral monitoring in comatose head-injured patients. Acta Neurochir (Wien). 1998;140(4):357-365.

9. Cremer OL, van Dijk GW, van Wensen E, et al. Effect of intracranial pressure monitoring and targeted intensive care on functional outcome after severe head injury. Crit Care Med. 2005;33(10):2207-2213.

10. Bouzat P, Marques-Vidal P, Zerlauth JB, et al. Accuracy of brain multimodal monitoring to detect cerebral hypoperfusion after traumatic brain injury. Crit Care Med. 2015;43(2):445-452.

11. Clifton GL, Jiang JY, Lyeth BG, Jenkins LW, Hamm RJ, Hayes RL. Marked protection by moderate hypothermia after experimental traumatic brain injury. J Cereb Blood Flow Metab. 1991;11(1):114-121.

12. Bramlett HM, Green EJ, Dietrich WD, Busto R, Globus MY, Ginsberg MD. Posttraumatic brain hypothermia provides protection from sensorimotor and cognitive behavioral deficits. J Neurotrauma. 1995;12(3):289-298.

13. Ahmed AI, Bullock MR, Dietrich WD. Hypothermia in traumatic brain injury. Neurosurg Clin N Am. 2016;27(4):489-497.

Dove Medical Press encourages responsible, free and frank academic debate. The content of the Neuropsychiatric Disease and Treatment 'letters to the editor' section does not necessarily represent the views of Dove Medical Press, its officers, agents, employees, related entities or the Neuropsychiatric Disease and Treatment editors. While all reasonable steps have been taken to confirm the content of each letter, Dove Medical Press accepts no liability in respect of the content of any letter, nor is it responsible for the content and accuracy of any letter to the editor.

\section{Publish your work in this journal}

Neuropsychiatric Disease and Treatment is an international, peerreviewed journal of clinical therapeutics and pharmacology focusing on concise rapid reporting of clinical or pre-clinical studies on a range of neuropsychiatric and neurological disorders. This journal is indexed on PubMed Central, the 'PsycINFO' database and CAS, and is the official journal of The International Neuropsychiatric Association (INA). The manuscript management system is completely online and includes a very quick and fair peer-review system, which is all easy to use. Visit http://www.dovepress.com/testimonials.php to read real quotes from published authors. 